\title{
The Practice of the Sino-foreign Cooperation in Running Schools of Engineering Disciplines
}

\author{
Zeng-Zhong Wang ${ }^{1, a,{ }^{*}}$, Yu-Xin Zhang ${ }^{1, b}$, I. Smith ${ }^{2, c}$ \\ ${ }^{1}$ College of Civil Engineering of Shanghai Normal University, Shanghai, China \\ ${ }^{2}$ School of Engineering and the Built Environment, Edinburgh Napier University, Edinburgh, UK

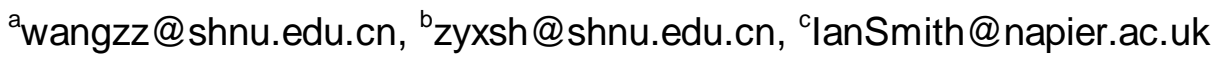 \\ ${ }^{*}$ Corresponding author
}

Keywords: Engineering disciplines, Sino-foreign cooperation, Internationalization.

\begin{abstract}
Lying in a transformation period of economic development, economic prosperity, social progress and development in science and technology have to rely on strong competitiveness of a nation's universities to a large degree. Internationalising education is seen as playing a role in the empowerment of students through the acquisition of skills to help them become more independent, more able to participate in society and able to make the most of the opportunities which are presented to them. Shanghai Normal University (SNU) and Edinburgh Napier University (ENU) offer a joint undergraduate programme in Civil Engineering. The programme began in 2007, four graduates have been remarkable, of course also encountered some problems and frustrations. In this paper, the program was introduced, the operation process of the project, curriculum setting, teaching resources introduction, teaching management and engineering discipline professional the difficulties encountered in the process of Sino-foreign cooperation in running schools, summarizes problems and their solutions, to share experiences and lessons.
\end{abstract}

\section{Introduction}

Internationalising education is seen as playing a role in the empowerment of students through the acquisition of skills to help them become more independent, more able to participate in society and able to make the most of the opportunities which are presented to them [1, 2]. In Sino-foreign cooperative running of school, by introducing foreign educational institutions' school running ideas, attracting excellent foreign teachers to participate in teaching, absorbing foreign educational resources, utilizing advanced teaching methods such as case teaching, class discussion, debate and demonstrative teaching, students will get in touch with and learn about the interactive and heuristic teaching methods adopted by foreign educational institutions and realize complementary advantages [3,4]. Shanghai Normal University (SNU) and Edinburgh Napier University (ENU) offer a joint undergraduate programme in Civil Engineering. The programme began in 2007, four graduates have been remarkable, of course also encountered some problems and frustrations. In this paper, the joint program was introduced, the operation process of the project, curriculum setting, teaching resources introduction, teaching management and engineering discipline professional the difficulties encountered in the process of Sino-foreign cooperation in running schools, summarizes problems and their solutions, to share experiences and lessons.

\section{SNU- ENU Collaborative Programme}

\section{Historical Development}

The dual-award programme of SNU and ENU in Civil Engineering is fully approved by the Ministry of Education (MoE) on August 29, 2006 and is accredited by the Professional Body for Civil Engineering in the UK (the Institution of Civil Engineers). Such professional accreditation enables graduates to practice as fully qualified civil engineers throughout the world. The programme has received high recognition 
from authorities in both countries for its role in providing a truly international experience for the students. The cooperative education model is of " $3+1$ ", students study Years 1 to 3 in Shanghai (with a large amount of teaching delivered by ENU staff) before studying Year 4 in Edinburgh. These eligible students can obtain ENU degree also can obtain degree certificate and graduation certificate at SNU.

In total, more than one-third of the entire professional or technical course is taught in English. To enable this, staff from ENU teaches in Shanghai during Years 2 and 3. In this way, the students start to appreciate the significance of the English language throughout their studies, and naturally gain knowledge of the technical subjects in a truly international manner. This is readily achievable by most students having studied these modules in English in Shanghai.

The annual programme review event held in alternating cities (Edinburgh / Shanghai) allows the Management Board to reflect on the successes and issues arising during the previous session. This enables an action plan to be established to ensure the smooth operation of the programme continues.

\section{Joint-Programme Objectives}

The programme was established to provide the Chinese civil engineering undergraduates the opportunity to experience a truly international component to their studies. To this end the following objectives were identified to enable appropriate programme development $[5,6]$ :

1) To provide civil engineering undergraduates from Shanghai Normal University with a significant international component to their studies;

2) To provide civil engineering undergraduates from Shanghai Normal University with the opportunity to achieve a joint degree in civil engineering; the exiting qualification is the internationally recognised BSc (Honours) Civil Engineering;

3) To enable civil engineering undergraduates from Shanghai Normal University to significantly improve their written, spoken and technical English;

4) To provide civil engineering undergraduates from Edinburgh Napier University with the opportunity to study alongside a number of international students in their honours year;

5) To provide sustainable, enhanced fee income generation for both Edinburgh Napier University and Shanghai Normal Universities.

\section{The operation process of the programme}

Session 2013 - 14 saw the 7 year milestone in the delivery of the programme and now is an appropriate time to reflect on and assess the success of the programme. During development, the strategically important Professional Body (UK) and Government (China) approvals for the programme were gained. To ensure the smooth running of the programme, a Management Board has been established with the responsibility of agreeing programme content, methods of delivery, teaching support requirements, administrative and contractual issues, and working with the MoE and the JBM as appropriate to ensure sustained approval and accreditation. The Board comprises senior staff from both universities, and is a separate body from the programme's teaching teams. The programme has rapidly become widely respected as a flagship model for a truly UK-Chinese collaboration educational course.

To date, all SNU students have coped well with the transition to Edinburgh Napier and have established friendships with other students. Typically between 26 and 30 SNU students study at ENU in Year 4 and all have an enjoyable and rewarding experience in Edinburgh. Indeed, on average, about 30\% of the SNU graduates gain a first class honours degree as shown in table 1 and the majority continue to Masters Level at Edinburgh Napier and at other UK universities.

Students studying in Edinburgh experience a truly international dimension to their studies. Mixing with students of many other (mainly European) nationalities gives the Chinese students a real international experience. It is clear that the planning and delivery of the programme is fully successful and the students had had a memorable experience in Edinburgh. This illustrates that not only does their year at ENU fulfill their immediate needs, but it also prepares them for further, higher studies, which will prepare them fully for their future careers. 
Tab.1 the statistics of degree level of SNU students in ENU

\begin{tabular}{c|c|c|c}
\hline Year & No. of SNU students to UK & $\begin{array}{c}\text { No. of SNU students } \\
\text { gain first class honours } \\
\text { degree }\end{array}$ & $\begin{array}{c}\text { No. of SNU students } \\
\text { gain second class honours } \\
\text { degree }\end{array}$ \\
\hline 2011 & 25 & 6 & 12 \\
\hline 2012 & 25 & 11 & 13 \\
\hline 2013 & 26 & 11 & 13 \\
\hline 2014 & 38 & 13 & 16 \\
\hline Total & 114 & 43 & 54 \\
\hline
\end{tabular}

\section{Additional Benefits of the Collaboration}

In addition to the collaborative programme in civil engineering, by both institutions working so closely together, additional opportunities present themselves for further collaboration for mutual benefit. The Collaboration Agreement makes provision for staff exchange and each year staff from SNU visit Edinburgh Napier University for a period of 3 months for teaching observation and access to learning resources in Edinburgh. This enables the SNU staff to see first-hand the methods and styles of teaching, learning and assessment adopted in the UK. Visiting scholars are also able to contribute to the teaching and project supervision activities at ENU such that both students and staff alike gain from the experience. In addition to this, naturally when institutions collaborate, opportunities for joint research and joint $\mathrm{PhD}$ supervision are investigated. Although Edinburgh Napier and Shanghai Normal are not yet carrying out joint research work, it is hoped that this is something that will happen in the near future.

\section{Summary}

It is essential that undergraduate students within the engineering profession be prepared for working in an increasingly international society. University engineering departments must therefore develop strategies that provide the global perspectives and international experiences that will help graduates excel in this new world order. The direct contact with persons with different cultural backgrounds can form an efficient, effective and stimulating means to learn about the differences in geographies and teaching methods. In light of recent economic events, preparing students for international travel to obtain work in their chosen profession has become even more critical.

\section{References}

[1] Lihui Xie (2011). Strategic Alliance: Competitiveness of Sino-Foreign Cooperative School Running Operation. International Education Studies, Vol. 4, No. 1; February 2011.

[2] Chinese Ministry of Education, Decree No. 15. The interim measures for the administration of overseas education of colleges and universities. Feb 1, 2003. (in Chinese)

[3] Lin Jinhui. On the Introduction of Educational Resources with High Quality in Sino-foreign Cooperative School Running[J], Education Research, 2012(10). (in Chinese)

[4] Borri, C., Guberti, E. and Melsa, J. (2007) "International dimensions in engineering education", European Journal of Engineering Education, 32(6), 627-637.

[5] Harris, S. (2008) "Internationalizing the University", Educational Philosophy and Theory, 40(2), 346-357.

[6] Smith, I., Liu, J., McDougall, J. and Zhang, H. (2012) "Collaborative programme in Civil Engineering between Edinburgh Napier University (UK) and Shanghai Normal University (China)", Proceedings of INTED2012 Conference, Valencia, Spain. 